\title{
Alveolar Cell Senescence Exacerbates Pulmonary Inflammation in Patients with Chronic Obstructive Pulmonary Disease
}

\author{
Takao Tsuji Kazutetsu Aoshiba Atsushi Nagai \\ First Department of Medicine, Tokyo Women's Medical University, Tokyo, Japan
}

\section{Key Words}

Alveolar epithelial cell • Cellular senescence .

Inflammation $\cdot$ Chronic obstructive pulmonary disease $\cdot$

NF-KB

\begin{abstract}
Background: Alveolar cell senescence is accelerated in patients with chronic obstructive pulmonary disease (COPD). Objectives: We tested the hypothesis that alveolar cell senescence contributes to the chronic inflammation that affects the lungs of COPD patients. Methods: We exposed alveolar type II-like epithelial (A549) cells to a G-quadruplexinteracting telomerase inhibitor in vitro to induce cellular senescence and analyzed the production of proinflammatory cytokines and the activation of NF-кB. Human dermal microvascular endothelial cells (HDMECs) were serially passaged to induce replicative senescence. We also immunostained human lung tissue sections obtained from COPD patients, asymptomatic smokers and asymptomatic nonsmokers and examined correlations between type II cell senescence and inflammation. Results: Senescent A549 cells and HDMECs, whether stimulated with lipopolysaccharide or not, produced greater amounts of IL- $6, \mathrm{IL}-8$ and TNF- $\alpha$, which paralleled NF- $\kappa B$ activation, than did presenescent cells. There were positive correlations between the percent-
\end{abstract}

ages of senescent type II cells that expressed p16 ${ }^{\text {INK4a }}$ and the percentages of type II cells that expressed phosphorylated NF- $\mathrm{kB}$. The lung tissue of the COPD patients contained higher percentages of proinflammatory senescent type II cells that co-expressed $\mathrm{p} 16^{\mathrm{INK} 4 \mathrm{a}}$ and phosphorylated NF- $\mathrm{KB}$ than the tissue from asymptomatic smokers and asymptomatic nonsmokers. Higher percentages of p $16^{\mathrm{INK} 4 \mathrm{a}}$-positive senescent type II cells than of $\mathrm{p} 16^{\mathrm{INK} 4 \mathrm{a}}$-negative presenescent type II cells were positive for phosphorylated NF-кB. Conclusions: Senescence of alveolar epithelial cells is associated with functional alterations of the cells to a proinflammatory phenotype and may contribute to the pathogenesis of COPD.

Copyright $\odot 2009$ S. Karger AG, Basel

\section{Introduction}

The aging process is characterized by a low-grade, chronic, systemic inflammatory state, and the term 'inflamm-aging' has been coined to characterize this phenomenon [1]. Inflamm-aging, i.e. age-related inflammation, is exemplified by evidence that plasma IL- 6 and other proinflammatory cytokine levels start to increase in healthy people at about $50-60$ years of age [1-3]. The numbers of neutrophils, macrophages, $\mathrm{T}$ lymphocytes

\section{KARGER}

Fax +41613061234 E-Mail karger@karger.ch www.karger.com
(C) 2009 S. Karger AG, Basel

0025-7931/10/0801-0059\$26.00/0

Accessible online at:

www.karger.com/res
Kazutetsu Aoshiba, MD

First Department of Medicine, Tokyo Women's Medical University

8-1 Kawada-cho, Shinjuku-ku

Tokyo 162-8666 (Japan)

Tel. +81 33353 8111, Fax +81 35379 5457, E-Mail kaoshiba@ chi.twmu.ac.jp 
and B lymphocytes of elderly people and aged animals have also been shown to be increased in the lung tissue and bronchoalveolar fluid, providing additional evidence of inflamm-aging $[4,5]$. Thus, inflamm-aging has both local and systemic effects, potentially predisposing to a variety of age-related chronic inflammatory diseases, such as atherosclerosis, osteoarthritis, diabetes mellitus and chronic obstructive pulmonary disease (COPD) $[1$, 6]. Inflamm-aging may be the consequence of continuous exposure to antigens in the form of pathogens, allergens, food and air pollution, or of increased oxidative stress resulting from the lifelong respiratory burst $[1,7,8]$. However, recent evidence suggests that senescence at the cellular level may contribute to the mechanism of inflamm-aging [9].

Cellular senescence is a state of irreversible growth arrest induced by telomere shortening (replicative senescence) or by telomere-independent signals such as DNA damage and oxidative stress (stress-induced premature senescence) $[10,11]$. Cellular senescence is thought to be responsible for the decline in cell proliferative capacity during normal aging and in age-related diseases $[12,13]$. We and others have recently reported that senescence of alveolar type II epithelial cells, endothelial cells and fibroblasts in the lungs of COPD patients is accelerated more rapidly than in normal lungs, suggesting that cellular senescence contributes to the impaired lung tissue maintenance in COPD patients [14-16]. Since COPD is associated with chronic lung inflammation as well as with impaired lung tissue maintenance [17], we hypothesized that cellular senescence also contributes to a chronic inflammatory state that affects the lungs of COPD patients. Here, we report our finding that alveolar epithelial cells undergoing senescence are transformed to a proinflammatory phenotype, which may promote inflammation in the lungs of COPD patients.

\section{Materials and Methods}

Induction of Cellular Senescence of A549 Cells

The alveolar type II-like epithelial cell line A549 (ATCC No. CCL-185) was maintained in Dulbecco's modified Eagle's medium (DMEM) supplemented with 10\% FCS under a humidified atmosphere of $5 \% \mathrm{CO}_{2}$ in air. All culture plates were coated with type I collagen (Vitrogen ${ }^{\circledR}$, Cohesion, Palo Alto, Calif., USA). To induce cellular senescence, A549 cells $\left(1.5 \times 10^{4} \mathrm{cells} / \mathrm{cm}^{2}\right)$ were seeded and allowed to attach to $100-\mathrm{mm}$ tissue culture plates containing DMEM supplemented with 10\% FCS. After $24 \mathrm{~h}$, they were rinsed with PBS and replenished with DMEM supplemented with $10 \%$ FCS in the presence or absence of the G-quadruplex-interacting agent, 2,6-bis[3-(N-piperidino)propionamido]anthra- cene-9,10-dione (1 $\mu \mathrm{M}$; No. 581005, Calbiochem, Gibbstown, N.J., USA), a potent telomerase inhibitor that binds to the telomeric G-quadruplex $[18,19]$. The cell culture was subjected to passage every 5 days, and at each passage cells were trypsinized and $1.5 \times 10^{4}$ cells $/ \mathrm{cm}^{2}$ were seeded onto $100-\mathrm{mm}$ tissue culture plates containing DMEM supplemented with 10\% FCS. After $24 \mathrm{~h}$, the cells were rinsed with PBS, and after replenishing the DMEM supplemented with $10 \%$ FCS with or without the G-quadruplex-interacting agent, they were allowed to grow for an additional 4 days until the next passage. Population doubling (PD) at each passage was calculated using the following formula: $\mathrm{PD}=$ $\ln$ (number of cells recovered/number of cells inoculated)/ln 2 . After 30 days of culture, the cells were rinsed with PBS and incubated for $12 \mathrm{~h}$ in serum-free DMEM with or without $10 \mu \mathrm{g} / \mathrm{ml}$ lipopolysaccharide (LPS; Escherichia coli serotype 055, Sigma-Aldrich, St. Louis, Mo., USA). At the end of the culture period, supernatants were recovered, clarified by centrifugation at $1,000 \mathrm{~g}$ for $10 \mathrm{~min}$ and stored at $-70^{\circ} \mathrm{C}$. In some experiments, culture supernatants collected after 10 or 20 days of culture were also stored. The cell monolayers were used for senescence-associated $\beta$-galactosidase (SA $\beta$-gal) staining or for analysis of NF- $\mathrm{B}$ transactivation.

Human dermal microvascular endothelial cells (HDMECs; Cat. No. 2000, Sciencell, Carlsbad, Calif., USA) were maintained in endothelial cell medium (Sciencell) supplemented with $10 \%$ FCS and serially propagated. All culture plates were coated with fibronectin (Sigma-Aldrich). At the end of the culture period, the cells were rinsed with PBS and incubated for $12 \mathrm{~h}$ in serum-free endothelial cell medium. Then, supernatants were recovered, and the cell monolayers were used for SA $\beta$-gal staining.

\section{SA $\beta$-Gal Staining}

SA $\beta$-gal staining was performed according to a previously described method [20]. The cells were fixed with $2 \%$ formaldehyde and $0.2 \%$ glutaraldehyde in PBS for 5 min at room temperature. The slides were then rinsed with PBS and incubated with an SA $\beta$-gal staining solution containing $40 \mathrm{~mm}$ sodium citrate $(\mathrm{pH}$ 6.0), $150 \mathrm{mM} \mathrm{NaCl}, 5 \mathrm{~mm}$ potassium ferricyanide, $5 \mathrm{mM}$ potassium ferrocyanide, $2 \mathrm{mM} \mathrm{MgCl}_{2}$ and $1 \mathrm{mg} / \mathrm{ml}$ 5-bromo-4-chloro3 -indolyl- $\beta$-D-galactoside.

NF- $\kappa B$ Transactivation Assay

Nuclear extracts were prepared with a TransAM nuclear extract kit (Active Motif, Carlsbad, Calif., USA), and binding of the p65/relA subunit of NF- $\kappa$ B was measured using a TransAM NF$\kappa \mathrm{B}$ p65 kit (Active Motif) according to the manufacturer's protocols. Briefly, nuclear extracts $(10 \mu \mathrm{g})$ were incubated for $1 \mathrm{~h}$ in a 96-well plate coated with NF- $\kappa$ B consensus oligonucleotides. After incubation with anti-p65 NF- $\kappa \mathrm{B}$ antibody, horseradish peroxidase-conjugated antibody was added to the wells for $1 \mathrm{~h}$. The wells were then washed, and after incubation with a 3,3',5,5'-tetramethylbenzidine substrate solution, the reaction was stopped by adding $0.5 \mathrm{M} \mathrm{H}_{2} \mathrm{SO}_{4}$, and absorbance at $450 \mathrm{~nm}$ was read on a spectrophotometer.

ELISA

The amounts of IL-6, IL- 8 and TNF- $\alpha$ in the culture supernatants were measured using ultrasensitive ELISA kits according to the manufacturer's instructions (Biosource International, $\mathrm{Ca}$ marillo, Calif., USA). 
Table 1. Characteristics of the subjects

\begin{tabular}{lccc}
\hline & $\begin{array}{l}\text { COPD } \\
(\mathrm{n}=8)\end{array}$ & $\begin{array}{l}\text { Smokers } \\
(\mathrm{n}=9)\end{array}$ & $\begin{array}{l}\text { Nonsmokers } \\
(\mathrm{n}=7)\end{array}$ \\
\hline Males/females, $\mathrm{n}$ & $8 / 0$ & $8 / 1$ & $2 / 5$ \\
Age, years & $64.8 \pm 3.0$ & $61.7 \pm 4.9$ & $63.4 \pm 3.4$ \\
Cigarettes, pack years & $65.1 \pm 8.4$ & $49.9 \pm 7.7$ & 0 \\
FEV $_{1}$, liters & $0.77 \pm 0.09^{* *}$ & $2.03 \pm 0.14$ & $2.14 \pm 0.15$ \\
$\mathrm{FEV}_{1} / \mathrm{FVC}, \%$ & $32.4 \pm 4.9^{* *}$ & $75.6 \pm 6.3$ & $76.4 \pm 6.1$ \\
$\mathrm{FEV}_{1}, \%$ predicted & $22.9 \pm 3.9^{* *}$ & $75.9 \pm 5.3$ & $87.1 \pm 2.6$ \\
\hline
\end{tabular}

The COPD patients and smokers were ex-smokers. ${ }^{* *} \mathrm{p}<0.01$ compared to asymptomatic smokers and nonsmokers.

\section{Immunohistochemistry}

Lung tissue blocks were obtained from 8 COPD patients [forced expiratory volume in $1 \mathrm{~s}\left(\mathrm{FEV}_{1}\right) /$ forced vital capacity (FVC) $<70 \%$ ] during volume reduction surgery, from 9 asymptomatic smokers $\left(\mathrm{FEV}_{1} / \mathrm{FVC} \geq 70 \%\right)$ and from 7 nonsmokers during pulmonary resection for localized lung cancer. This retrospective study used a database whose contents partially overlap with the material used in a previous study [14]. The protocol of the study conformed to the Declaration of Helsinki, and informed consent was obtained from each patient. The characteristics of the subjects are shown in table 1 . The ages of the subjects in all 3 groups were similar, and the COPD patients and asymptomatic smokers were ex-smokers. Formalin-fixed, paraffin-embedded lung tissue sections were used for immunofluorescence staining. The primary antibodies used were goat polyclonal antisurfactant protein C (SP-C; Santa Cruz Biotechnology Inc., Santa Cruz, Calif., USA), rabbit polyclonal antiphosphorylated (Ser536) NF-кB antibody (Abcam Dako Japan, Tokyo, Japan) and mouse monoclonal anti-p16 ${ }^{\mathrm{INK} 4 \mathrm{a}}$ antibody (Santa Cruz). To expose the immunoreactive epitopes of phosphorylated NF- $\kappa \mathrm{B}$ and $\mathrm{p} 16^{\mathrm{INK4a}}$, the sections were autoclaved in a citrate buffer $(10$ $\mathrm{mM}, \mathrm{pH}$ 6.0) for $10 \mathrm{~min}$. Replacement of the primary antibodies with the same concentration of nonimmunized IgG did not result in positive staining. The secondary antibodies used were Alexa Fluor 350 antigoat IgG, Alexa Fluor 488 antirabbit IgG and Alexa Fluor 594 antimouse IgG (Invitrogen, Carlsbad, Calif., USA).

A single observer (T.T.) who was not informed of the clinical data examined 20 randomly selected microscopic fields of each slide at a magnification of $\times 400$. In each field, we calculated the percentage of the total number of cells positive for phosphorylated NF- $\mathrm{B}$ that was positive for SP-C, the percentage of the total number of cells positive for $\mathrm{p} 16^{\mathrm{INK} 4 \mathrm{a}}$ that was positive for SP-C, the percentage of the total number of cells positive for phosphorylated NF- $\mathrm{B}$ that was positive for both SP-C and $\mathrm{p} 16^{\mathrm{INK} 4 \mathrm{a}}$, the percentage of the total number of cells positive for phosphorylated NF- $\mathrm{B}$ that was positive for SP-C but negative for $\mathrm{p} 16^{\mathrm{INK} 4 \mathrm{a}}$ and the percentage of the total number of cells positive for both phosphorylated NF- $\kappa \mathrm{B}$ and $\mathrm{p} 16^{\mathrm{INK} 4 \mathrm{a}}$ that was positive for SP-C. The mean value of the percentages in all 20 fields was calculated for each patient.

Alveolar Cell Senescence Exacerbates Inflammation

\section{Statistical Analysis}

Data are means \pm SEM. Differences were evaluated for significance by Student's t test for simple comparisons or by a oneway analysis of variance followed by post hoc analysis with the Tukey-Kramer test for multiple comparisons. Data were tested for correlations by the Spearman rank correlation test. $\mathrm{p}<0.05$ was considered significant.

\section{Results}

\section{A G-Quadruplex-Interacting Agent Induces}

Senescence of A549 Cells

We initially investigated if the G-quadruplex-interacting agent, a potent telomerase inhibitor that binds to the telomeric G-quadruplex, would induce cellular senescence in alveolar type II-like A549 cells. A trypan blue exclusion test revealed that exposure to the G-quadruplex-interacting agent at a concentration of $2 \mu \mathrm{M}$ or higher caused cell death in more than $20 \%$ of a population of A549 cells, so a sublethal concentration of $1 \mu \mathrm{M}$ was used in experiments. We exposed A549 cells to the G-quadruplex-interacting agent for 30 days and observed a timedependent decrease in PD in comparison with control cells (fig. 1A). Morphological examination of cells after 30 days of culture with the G-quadruplex-interacting agent showed an increased proportion of the flat, enlarged cells characteristic of the senescent phenotype, and this was accompanied by increased SA $\beta$-gal activity (fig. 1B, C). These findings indicated that the G-quadruplex-interacting agent had induced senescence in A549 cells, confirming the results of previous studies $[18,19]$.

\section{Senescent Cells Produce Proinflammatory Mediators}

The amounts of IL-6, IL- 8 and TNF- $\alpha$ were significantly higher in the culture supernatants of A549 cells exposed to the G-quadruplex-interacting agent for 30 days than in those of unexposed cells (fig. 2). Stimulation of A549 cells with LPS increased their production of IL-6, IL- 8 and TNF- $\alpha$. The amounts of IL-6, IL- 8 and TNF- $\alpha$ after LPS stimulation were also higher in the culture supernatants of A549 cells exposed to the G-quadruplexinteracting agent than in those of the unexposed cells. Exposure to the G-quadruplex-interacting agent for only 10 days did not increase the production of IL-6, IL-8 and TNF- $\alpha$ by A549 cells (fig. 3), suggesting that the increase in production of these cytokines after exposure to the Gquadruplex-interacting agent was not due to a direct stimulatory effect on the cells. The DNA-binding activity of p65/relA NF- $\kappa$ B was significantly greater in the nuclear extracts of A549 cells exposed to the G-quadruplex- 


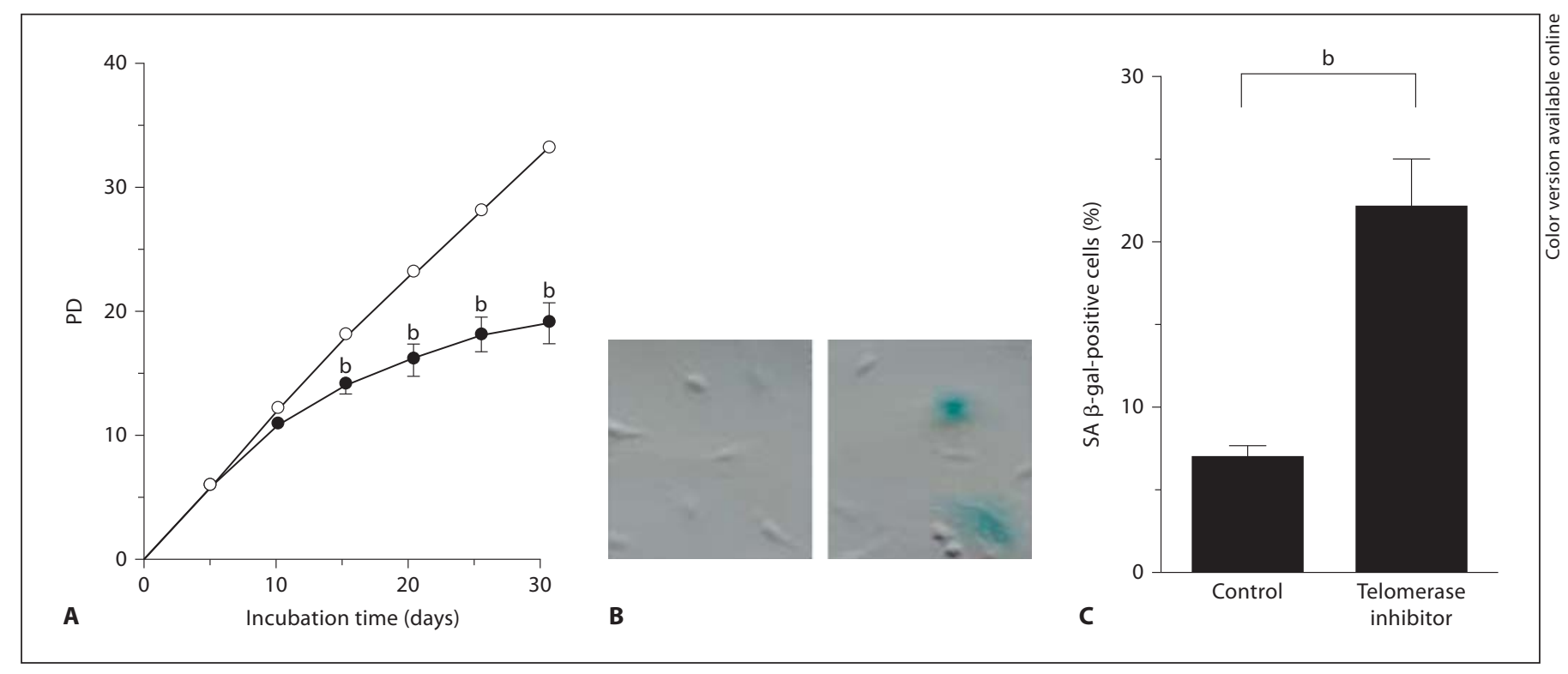

Fig. 1. Exposure of A549 cells to the G-quadruplex-interacting telomerase inhibitor 2,6-bis[3-(N-piperidino)propionamido]anthracene-9,10-dione induces cellular senescence. A PD of A549 cells exposed to $(\mathbf{0} ; n=5)$ and not exposed to $(\bigcirc ; n=5)$ the telomerase inhibitor. B Representative results of SA $\beta$-gal staining after 30 days of culture in the absence (left) or presence (right) of the telomerase inhibitor. A549 cells exposed to the telomerase inhibitor exhibited flat, enlarged cell morphology and increased SA $\beta$-gal activity. C Quantitative analysis of SA $\beta$-gal-positive cells after 30 days of culture in the presence $(n=5)$ or absence $(n=5)$ of the telomerase inhibitor. ${ }^{\mathrm{b}} \mathrm{p}<0.01$ compared to control cells. Data are expressed as the means \pm SEM.

interacting agent for 30 days than in those of untreated cells (fig. 4). Stimulation of A549 cells with LPS increased the DNA-binding activity of p65/relA NF- $\mathrm{KB}$ to higher levels in the nuclear extracts of A549 cells exposed to the G-quadruplex-interacting agent than in those of unexposed cells.

A549 cells are a cancer cell line, and to determine whether normal cells also exhibit proinflammatory phenotypes when they become senescent, we used HDMECs that had been serially passaged to induce cellular senescence. Morphological examination of HDMECs at $20 \mathrm{PD}$ showed an increased proportion of the flat, enlarged cells characteristic of the senescent phenotype associated with increased SA $\beta$-gal activity, as reported previously (fig. 5G, H) [21]. The amounts of IL-6, IL- 8 and TNF- $\alpha$ were significantly higher in the culture supernatants of HDMECs at $20 \mathrm{PD}$ than in those of HDMECs at $4 \mathrm{PD}$ (fig. 5A-F).

\section{Senescence of Type II Alveolar Cells Is Related to}

Chronic Lung Inflammation

The results obtained so far indicate that senescent A549 cells exhibit a proinflammatory phenotype, al- though A549 cells are not a good model for underlying processes in COPD. Since we have reported that senescence of alveolar type II epithelial cells in the lungs of COPD patients is accelerated more rapidly than in normal lungs [14], we sought to determine if the accelerated senescence of type II cells in the lungs of COPD patients contributes to inflammation. Because we found that the senescence of type II-like A549 cells is associated with NF- $\kappa B$ activation, we used an antiphosphorylated NF- $\kappa B$ antibody to immunostain sections of lung tissue. The same tissue sections were coimmunostained for $\mathrm{p} 16^{\text {INK4a }}$ (reliable marker of cellular senescence) [22] and SP-C (marker of type II cells). In the lungs of COPD patients, some of the type II cells that stained positive for SP-C coexpressed p16 $6^{\mathrm{INK} 4 \mathrm{a}}$ and phosphorylated NF- $\mathrm{KB}$ (fig. 6). Consistent with previous studies [14, 23], COPD patients had significantly higher percentages of type II cells that were positive for $\mathrm{p} 16^{\mathrm{INK} 4 \mathrm{a}}$ and phosphorylated NF- $\mathrm{KB}$ (separately) than did asymptomatic smokers and nonsmokers (fig. 7A, B). Asymptomatic smokers also had higher percentages of type II cells that were positive for p $16^{\text {INK4a }}$ and phosphorylated NF- $\kappa \mathrm{B}$ (separately) than did asymptomatic nonsmokers. COPD patients had high- 


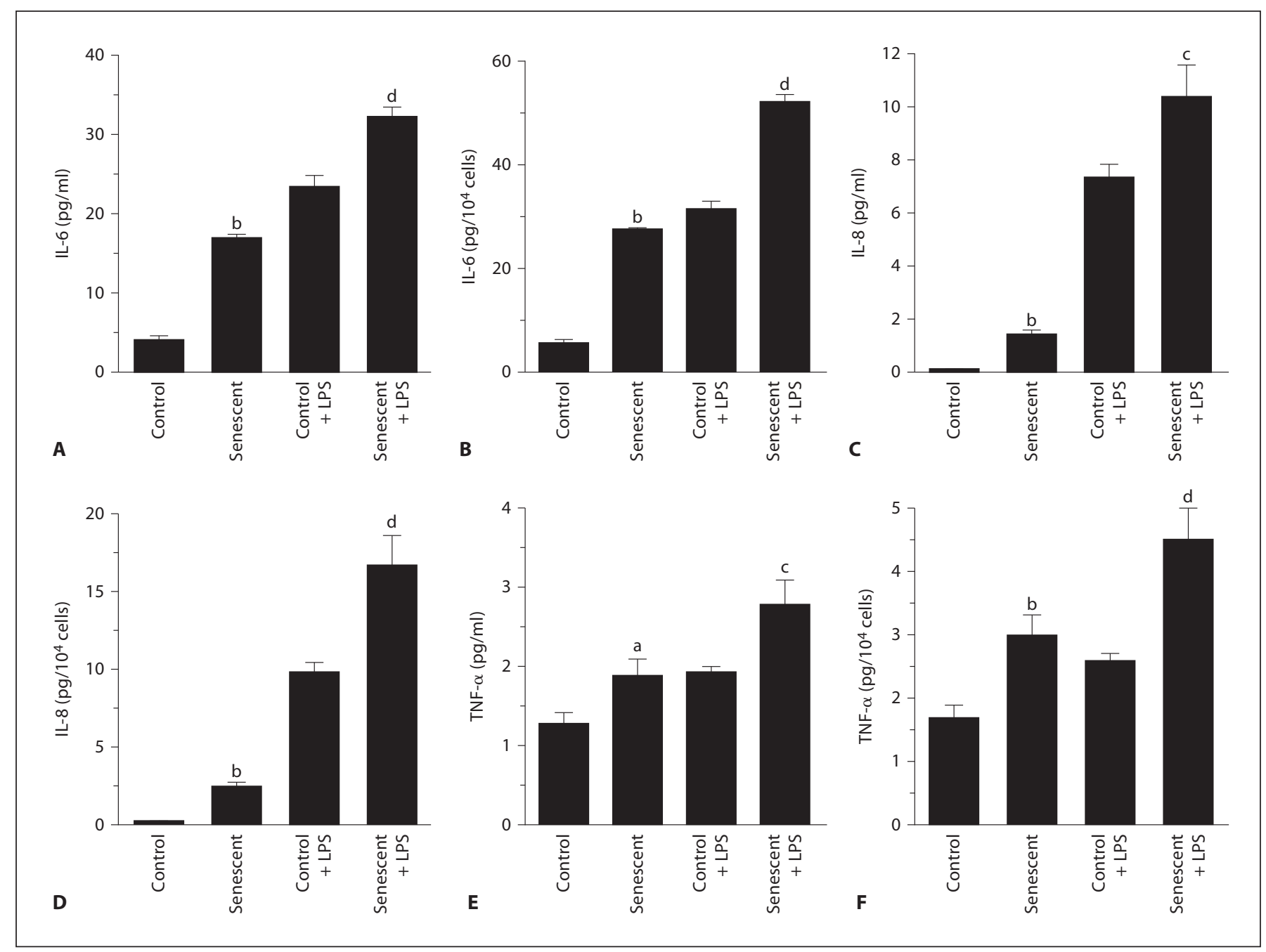

Fig. 2. Amounts of proinflammatory cytokines in the culture supernatants of A549 cells cultured for 30 days, with passages every 5 days, in the presence or absence of the G-quadruplex-interacting telomerase inhibitor 2,6-bis[3-(N-piperidino)propionamido]anthracene-9,10-dione. After 30 days of culture, cells were stimulated or not stimulated with LPS for $12 \mathrm{~h}$ before recovery of cell culture supernatants, and the amounts of IL-6 (A, B), IL-8 (C, D) and TNF- $\alpha$ (E, F) were measured by ELISA. Data are expressed as means \pm SEM, either uncorrected $(\mathbf{A}, \mathbf{C}, \mathbf{E})$ or corrected for cell number $(\mathbf{B}, \mathbf{D}, \mathbf{F}){ }^{\mathrm{a}} \mathrm{p}<0.05,{ }^{\mathrm{b}} \mathrm{p}<0.01$ compared to control cells not stimulated with LPS. ${ }^{c} \mathrm{p}<0.05,{ }^{\mathrm{d}} \mathrm{p}<0.01$ compared to control cells stimulated with LPS. $\mathrm{n}=5$ in each group.

er percentages of type II cells that expressed both $\mathrm{p} 16^{\mathrm{INK} 4 \mathrm{a}}$ and phosphorylated NF- $\kappa \mathrm{B}$ than did asymptomatic smokers and nonsmokers (fig. 7C). Asymptomatic smokers also had higher percentages of type II cells that expressed both p16 ${ }^{\text {INK4a }}$ and phosphorylated NF- $\kappa$ B than did asymptomatic nonsmokers. When all subjects were included in a correlation analysis, the percentage of p16 $6^{\mathrm{INK} 4 \mathrm{a}}$-positive type II cells was found to be strongly correlated with the percentage of phosphorylated NF$\kappa \mathrm{B}$-positive type II cells (fig. 7D).
To further investigate the relationship between senescence and NF- $\kappa \mathrm{B}$ activation at the cellular level, we compared the phosphorylated NF- $\kappa \mathrm{B}$ positivity of senescent type II cells that expressed $\mathrm{p} 16^{\mathrm{INK} 4 \mathrm{a}}$ and presenescent type II cells that did not express p16 ${ }^{\mathrm{INK} 4 \mathrm{a}}$. A higher percentage of senescent type II cells that expressed $16^{\text {INK4a }}$ was positive for phosphorylated NF- $\kappa \mathrm{B}$ than of presenescent type II cells that did not express p16 ${ }^{\mathrm{INK} 4 a}$ (fig. 8). Higher positive rates for phosphorylated NF- $\mathrm{\kappa B}$ of senescent type II cells than presenescent type II cells were ob- 


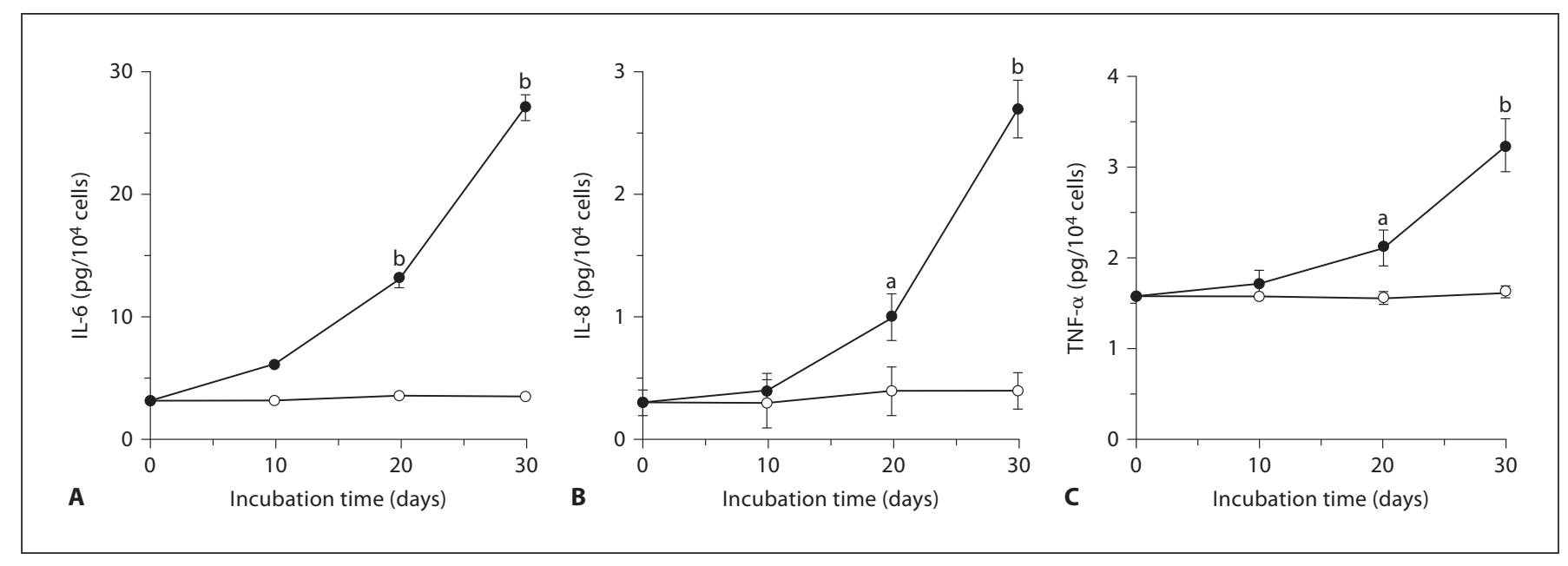

Fig. 3. A549 cell production of IL-6 (A), IL-8 (B) and TNF- $\alpha$ (C) is upregulated in a time-dependent manner after exposure to the telomerase inhibitor. $\mathbf{O}=$ A549 cells exposed to the telomerase inhibitor; $\bigcirc=$ control cells. ${ }^{\mathrm{a}} \mathrm{p}<0.05,{ }^{\mathrm{b}} \mathrm{p}<0.01$ compared to control cells. Data are expressed as the means \pm SEM. $\mathrm{n}=5$ in each group.

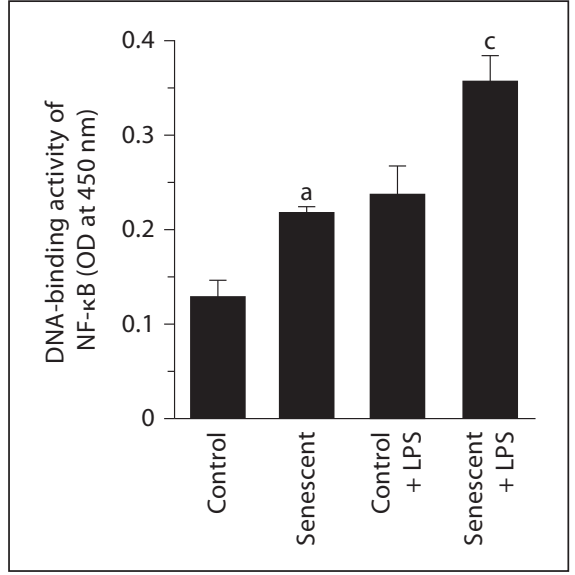

Fig. 4. DNA-binding activity of NF-кB in A549 cells treated as described in the legend to figure 2. The amount of nuclear p65/ relA NF- $\kappa \mathrm{B}$ bound to NF- $\kappa \mathrm{B}$ consensus oligonucleotides was measured with a TransAM NF- $\kappa B$ p 65 kit. ${ }^{a} \mathrm{p}<0.05$ compared to control cells not stimulated with LPS. ${ }^{c} \mathrm{p}<0.05$ compared to control cells stimulated with LPS. Data are expressed as the means \pm SEM. $\mathrm{n}=5$ in each group.

served in all of the subjects as a whole (fig. $8 \mathrm{~A}$ ) and in the subgroups of COPD patients (fig. 8B), asymptomatic smokers (fig. 8C) and nonsmokers (fig. 8D). These results suggest greater activation of NF- $\mathrm{KB}$ in senescent type II cells than in presenescent cells in the presence and absence of COPD. Comparison between the 3 groups of subjects showed that the lungs of COPD patients contained higher percentages of type II cells (whether positive or negative for $\mathrm{p} 16^{\mathrm{INK} 4 \mathrm{a}}$ ) that were positive for phosphorylated NF- $\kappa \mathrm{B}$ than did the lungs of asymptomatic smokers or nonsmokers (fig. 8B-D). The lungs of asymptomatic smokers contained higher percentages of type II cells (whether positive or negative for $\mathrm{p} 16^{\mathrm{INK} 4 \mathrm{a}}$ ) that were positive for phosphorylated NF- $\kappa \mathrm{B}$ than did the lungs of asymptomatic nonsmokers (fig. 8C, D).

\section{Discussion}

We and others have previously shown that the alveolar type II epithelial cells, endothelial cells and fibroblasts of COPD patients have an accelerated rate of cellular senescence that causes permanent loss of proliferative capacity $[14,15]$. In the present study, we demonstrated that senescent A549 cells, both stimulated and not stimulated with LPS, produce greater amounts of IL-6, IL- 8 and TNF- $\alpha$ in association with NF- $\kappa B$ activation than do presenescent cells. We also found that the percentages of $\mathrm{p} 16^{\mathrm{INK} 4 \mathrm{a}_{-}}$ positive type II cells in human lung tissue were positively correlated with the percentages of phosphorylated NF$\kappa \mathrm{B}$-positive type II cells. The COPD patients had higher percentages of type II cells that expressed p16 ${ }^{\mathrm{INK} 4 \mathrm{a}}$ and phosphorylated NF- $\kappa \mathrm{B}$ than did the asymptomatic smokers and nonsmokers. At the cellular level, higher percentages of $\mathrm{p} 16^{\mathrm{INK4a}}$-positive type II cells than p16 $6^{\mathrm{INK4a}}$-nega- 


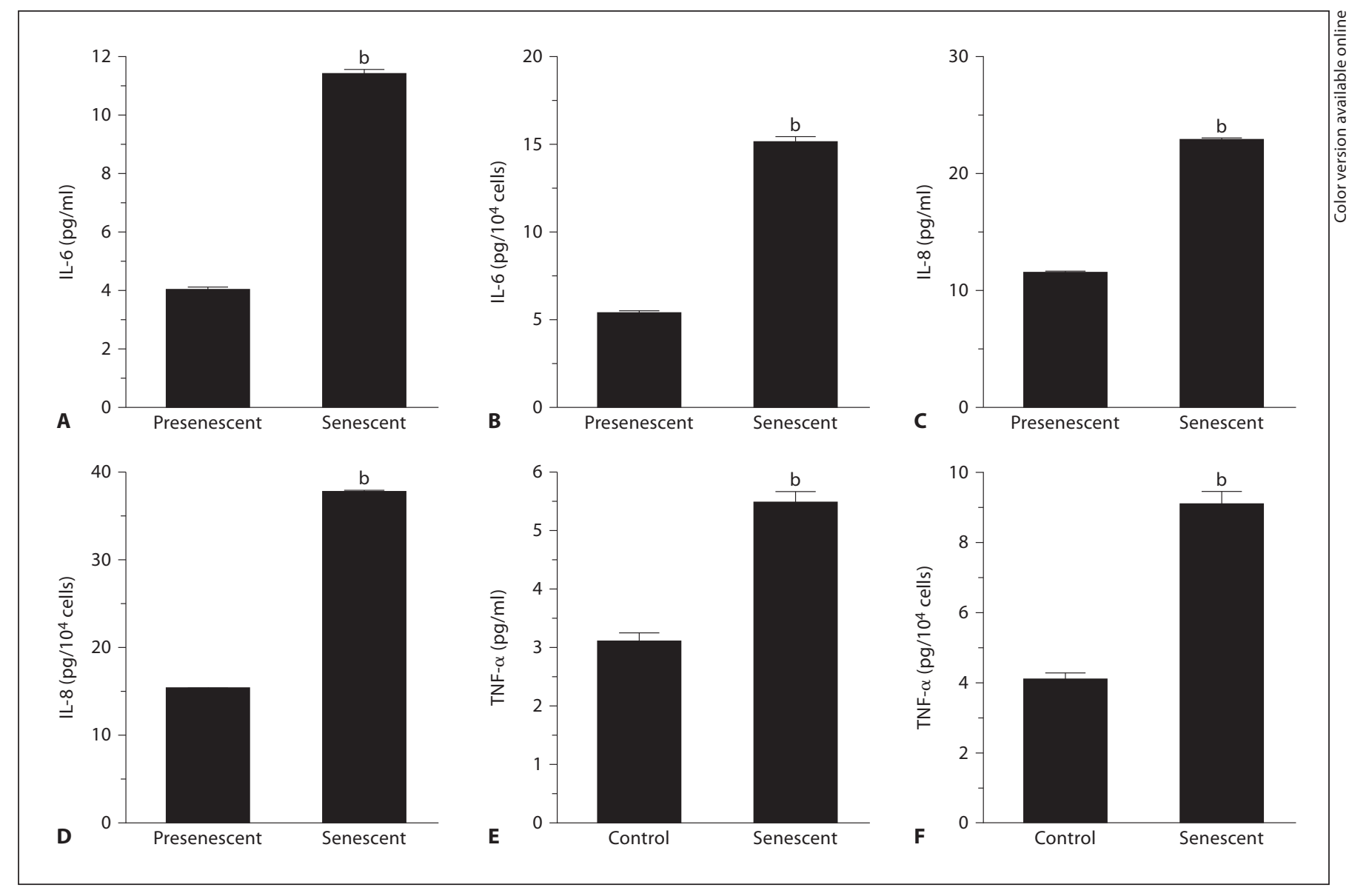

Fig. 5. Production of proinflammatory cytokines by presenescent (PD 4) and senescent (PD 20) HDMECs. A-F Amounts of IL-6 (A, B), IL-8 (C, D) and TNF- $\alpha$ (E, F) in the culture supernatants of HDMECs at PD 4 or PD 20. Data are expressed as means \pm SEM, either uncorrected $(\mathbf{A}, \mathbf{C}, \mathbf{E})$ or corrected for cell number $(\mathbf{B}, \mathbf{D}, \mathbf{F})$. ${ }^{\mathrm{b}} \mathrm{p}<0.01 . \mathrm{n}=5$ in each group. G, H SA $\beta$-gal staining of HDMECs at PD $4(\mathbf{G})$ and PD $20(\mathbf{H})$.
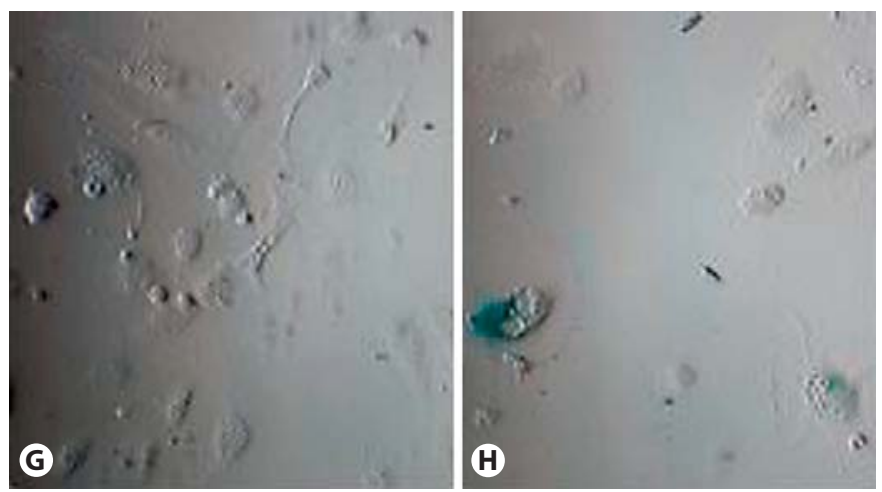

tive type II cells were positive for phosphorylated NF- $\kappa$ B. These results suggest that senescence of alveolar epithelial cells is associated with functional alterations of the cells to a proinflammatory phenotype.

The term 'cellular senescence' is used to describe aging on a cellular level that comprises a series of morphological and functional alterations, including loss of proliferative capacity. The results of our study suggest that cellular

senescence in the lungs not only limits cell proliferation but promotes inflammation, corroborating the results of previous studies that showed increased production of proinflammatory cytokines by different types of cells, such as fibroblasts and endothelial cells, that underwent senescence in vitro [24-26]. The overproduction of IL-6, IL- 8 and TNF- $\alpha$ by senescent alveolar epithelial cells observed in this study may result in the establishment of a 
Fig. 6. A-D Light microscopic (A) and corresponding epifluorescence (B-D) images of lung tissue sections obtained from COPD patients. B-G Sections were triple stained with antibodies against anti-SP-C (blue fluorescence; B, E), anti-p16 ${ }^{\mathrm{INK} 4 \mathrm{a}}$ (red fluorescence; C, F) and anti-phosphorylated-NF-кB (green fluorescence; D, G). E-G High-power magnification of epifluorescence images. $\mathbf{H}$ A merged image of $\mathbf{E}-\mathbf{G}$, showing a type II cell that stained positive for $\mathrm{p} 16^{\mathrm{INK} 4 \mathrm{a}}$ and phosphorylated NF- $\mathrm{KB}$ (arrow). The arrowhead points to a type II cell that stained negative for both $\mathrm{p}^{\mathrm{INK} 4 \mathrm{a}}$ and NF- $\kappa$ B. Scale bars $=20 \mu \mathrm{m}$. Colors refer to online version.

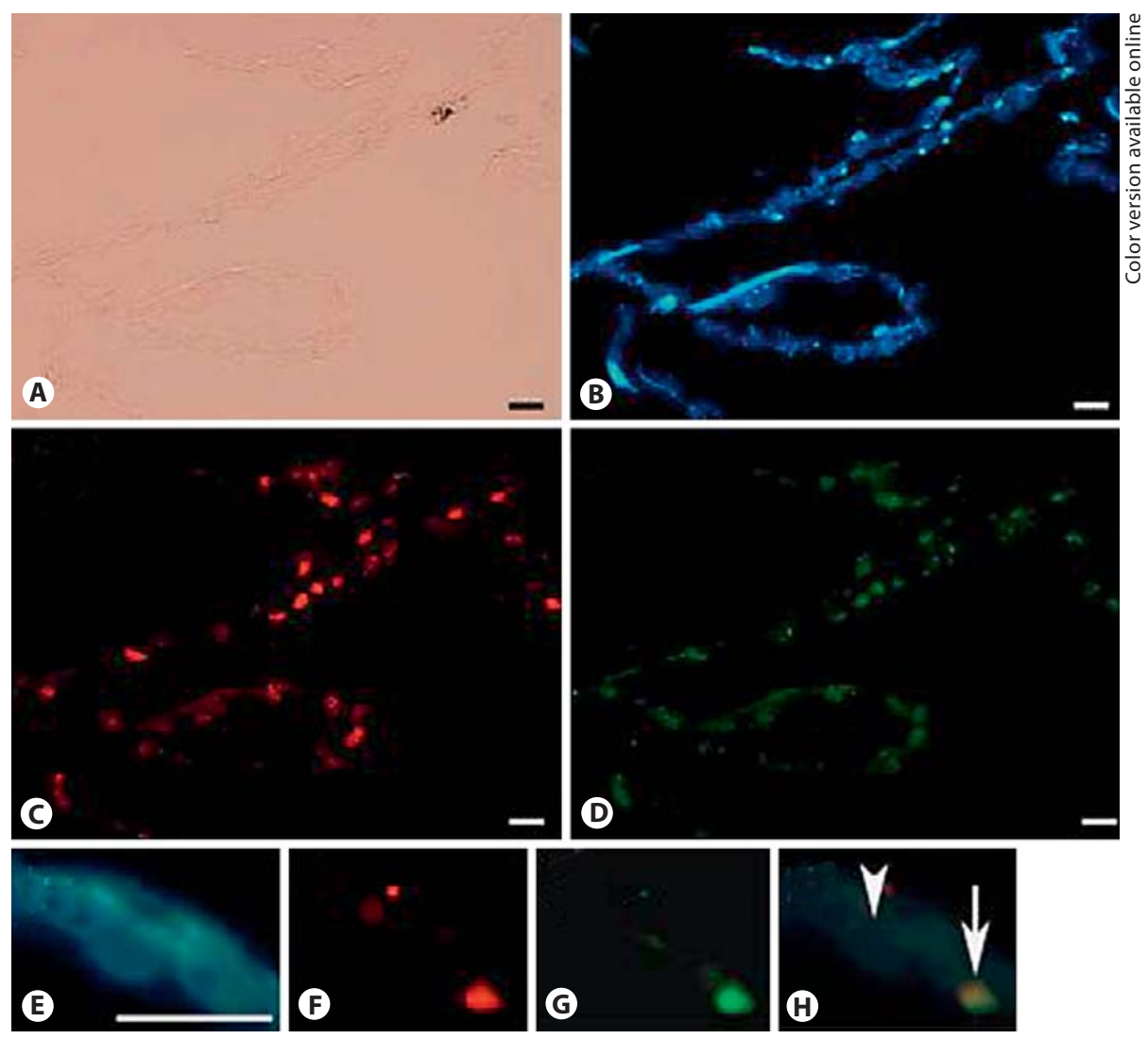

positive feedback loop, since TNF- $\alpha$, for example, activates NF- $\kappa$ B signaling in alveolar epithelial cells and thereby stimulates them to produce proinflammatory cytokines $[27,28]$.

Our findings in this study show that cellular senescence is associated with activation of NF- $\kappa \mathrm{B}$, the master transcription regulator of inflammation in a variety of age-related diseases, including atherosclerosis and COPD [29-31], corroborating the results of previous studies showing that NF- $\kappa \mathrm{B}$ is activated during aging at the cellular and organism levels. For example, constitutive activation and nuclear translocation of NF- $\mathrm{BB}$ has been $\mathrm{ob}-$ served both in fibroblasts subjected to replicative senescence in vitro and in samples of skin, brain, heart, vasculature, lymphoid and lung tissue from aged animals [26, 32-36]. These findings, together with our own, illustrate a critical role of NF- $\kappa \mathrm{B}$ that may account for chronic inflammation during normal aging and in age-related diseases [34, 35].

In the human lung tissue study, we found that the lungs of the COPD patients contained higher percentages of type II cells that express p16 ${ }^{\mathrm{INK} 4 \mathrm{a}}$, a marker of cellular senescence, and of type II cells that express phosphorylated NF- $\mathrm{B}$, a marker of NF- $\kappa \mathrm{B}$ activation, than did the lungs of asymptomatic smokers and nonsmokers (fig. 6), confirming previous findings, including our own, that showed accelerated senescence and functional activation of epithelial cells in COPD patients [14, 30, 31]. We also found that COPD patients had higher percentages of type II cells that express both $\mathrm{p} 16^{\mathrm{INK} 4 \mathrm{a}}$ and phosphorylated $\mathrm{NF}-\kappa \mathrm{B}$ than did the asymptomatic smokers and nonsmokers, suggesting that proinflammatory senescent type II cells accumulated in the lungs of COPD patients.

When all of the subjects were included in a correlation analysis, the percentages of $\mathrm{p} 16^{\mathrm{INK} 4 \mathrm{a}}$-positive type II cells were found to be strongly correlated with the percentages of phosphorylated NF- $\kappa \mathrm{B}$-positive type II cells, indicating an intimate relationship between cellular senescence and NF- $\kappa \mathrm{B}$ activation at the tissue level. At the cellular level, we also found that higher percentages of $\mathrm{p} 16^{\mathrm{INK} 4 \mathrm{a}_{-}}$ positive type II cells than of $\mathrm{p} 16^{\mathrm{INK} 4 \mathrm{a}}$-negative type II cells were positive for phosphorylated NF-кB. These results suggest that senescent type II cells exhibit a proinflammatory phenotype, supporting our in vitro findings. The 
Fig. 7. A-C Percentages of SP-C-positive type II cells that express p16 $6^{\mathrm{INK} 4 \mathrm{a}}(\mathbf{A})$ or phosphorylated NF- $\mathrm{KB}(\mathbf{B})$ and of SP-Cpositive type II cells that express both p16 ${ }^{\mathrm{INK} 4 \mathrm{a}}$ and phosphorylated NF- $\mathrm{KB}(\mathbf{C})$ in the lungs of COPD patients, asymptomatic smokers and asymptomatic nonsmokers. ${ }^{\mathrm{a}} \mathrm{p}<0.05,{ }^{\mathrm{b}} \mathrm{p}<0.01$. D Correlation between the percentage of SP-C-positive type II cells that express p16 $6^{\mathrm{INK} 4 \mathrm{a}}$ and the percentage of SP-C-positive type II cells that express phosphorylated NF- $\mathrm{KB}$. $\mathbf{0}=$ COPD patients; $\bigcirc=$ asymptomatic smokers; $\square=$ asymptomatic nonsmokers. Bars represent means.

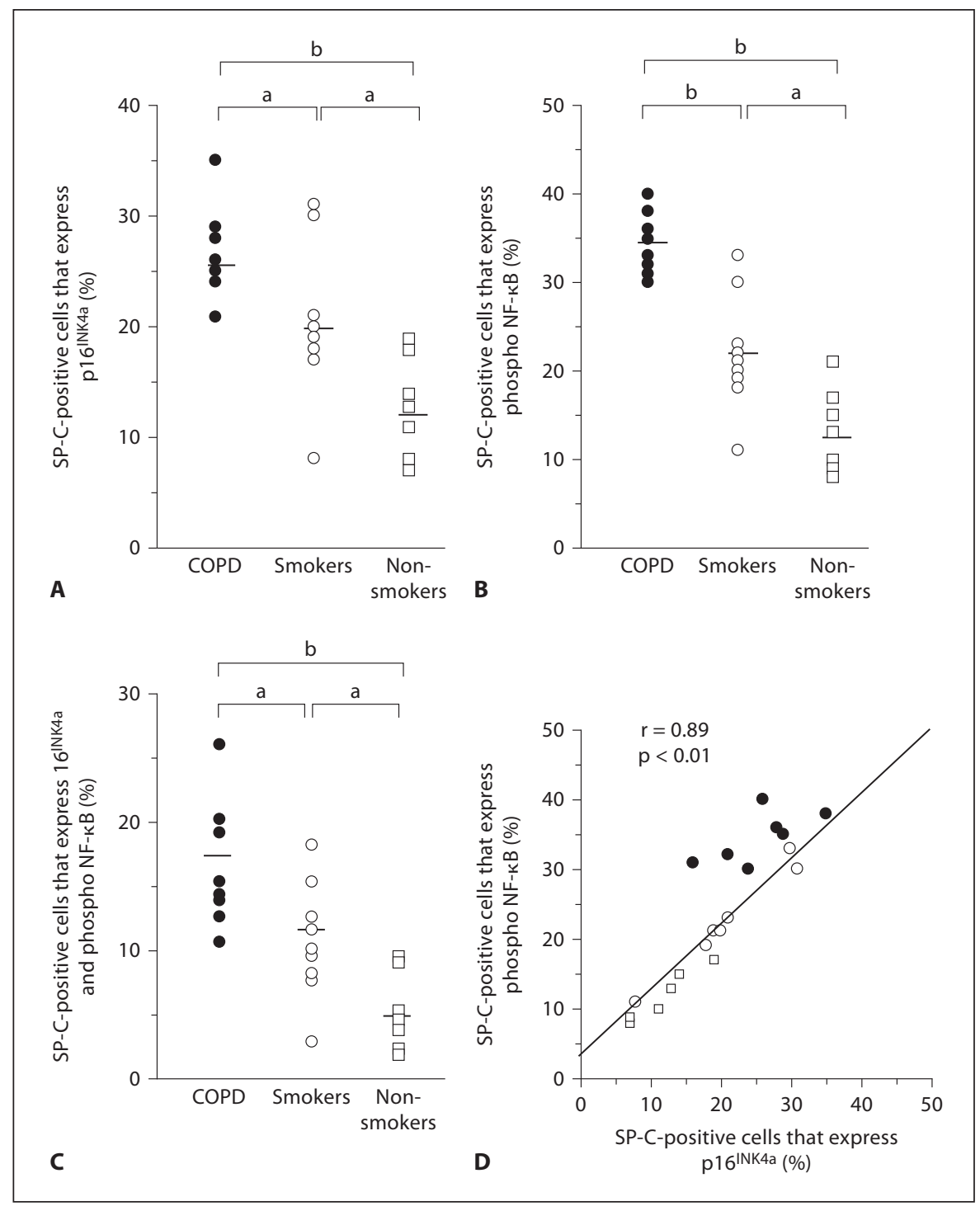

proinflammatory phenotype of senescent type II cells is not peculiar to COPD patients, because higher rates of phosphorylated NF- $\mathrm{B}$ positivity in $\mathrm{p} 16^{\mathrm{INK} 4 \mathrm{a}}$-positive type II cells than in $\mathrm{p} 16^{\mathrm{INK} 4 \mathrm{a}}$-negative type II cells were also observed in the lungs of asymptomatic smokers and nonsmokers. Thus, NF- $\kappa \mathrm{B}$ activation appears to be a common phenotype of senescent type II cells in COPD patients, asymptomatic smokers and asymptomatic nonsmokers. However, a higher percentage of type II cells, whether senescent or presenescent, was positive for phosphorylated NF- $\kappa \mathrm{B}$ in the COPD patients than in the asymptomatic smokers and nonsmokers. Furthermore, a higher percentage of type II cells, whether senescent or presenescent, was positive for phosphorylated NF- $\kappa$ B in the asymptomatic smokers than in the asymptomatic nonsmokers. Overall, these results suggest that NF- $\kappa B$ activity in type II cells is influenced by a history of smoking [37], by the presence of COPD and by cellular senescence.

We also found higher percentages of type II cells that expressed $\mathrm{p} 16^{\mathrm{INK4a}}$ and of type II cells that expressed both p16 ${ }^{\mathrm{INK} 4 \mathrm{a}}$ and phosphorylated NF- $\kappa \mathrm{B}$ in the lungs of the asymptomatic smokers than in the asymptomatic nonsmokers, suggesting that cigarette smoking contributes to the mechanism of type II cell senescence associated with NF- $\kappa \mathrm{B}$ activation and supporting previous evidence, including our own, showing that cigarette smoke accelerates cellular senescence in vitro $[20,38]$. The asymptomatic 
Fig. 8. Rates of immunopositivity for phosphorylated NF- $\mathrm{B}$ in cells that express both SP-C and $\mathrm{p} 16^{\mathrm{INK} 4 \mathrm{a}}$ and in cells that express SP-C but not p16 ${ }^{\mathrm{INK} 4 \mathrm{a}}$. A All subjects. B COPD patients. C Asymptomatic smokers. D Asymptomatic nonsmokers. ${ }^{\mathrm{b}} \mathrm{p}<0.01 .{ }^{\mathrm{d}} \mathrm{p}<0.01$ compared to asymptomatic smokers and nonsmokers. ${ }^{\mathrm{e}} \mathrm{p}<$ 0.05 compared to asymptomatic nonsmokers.

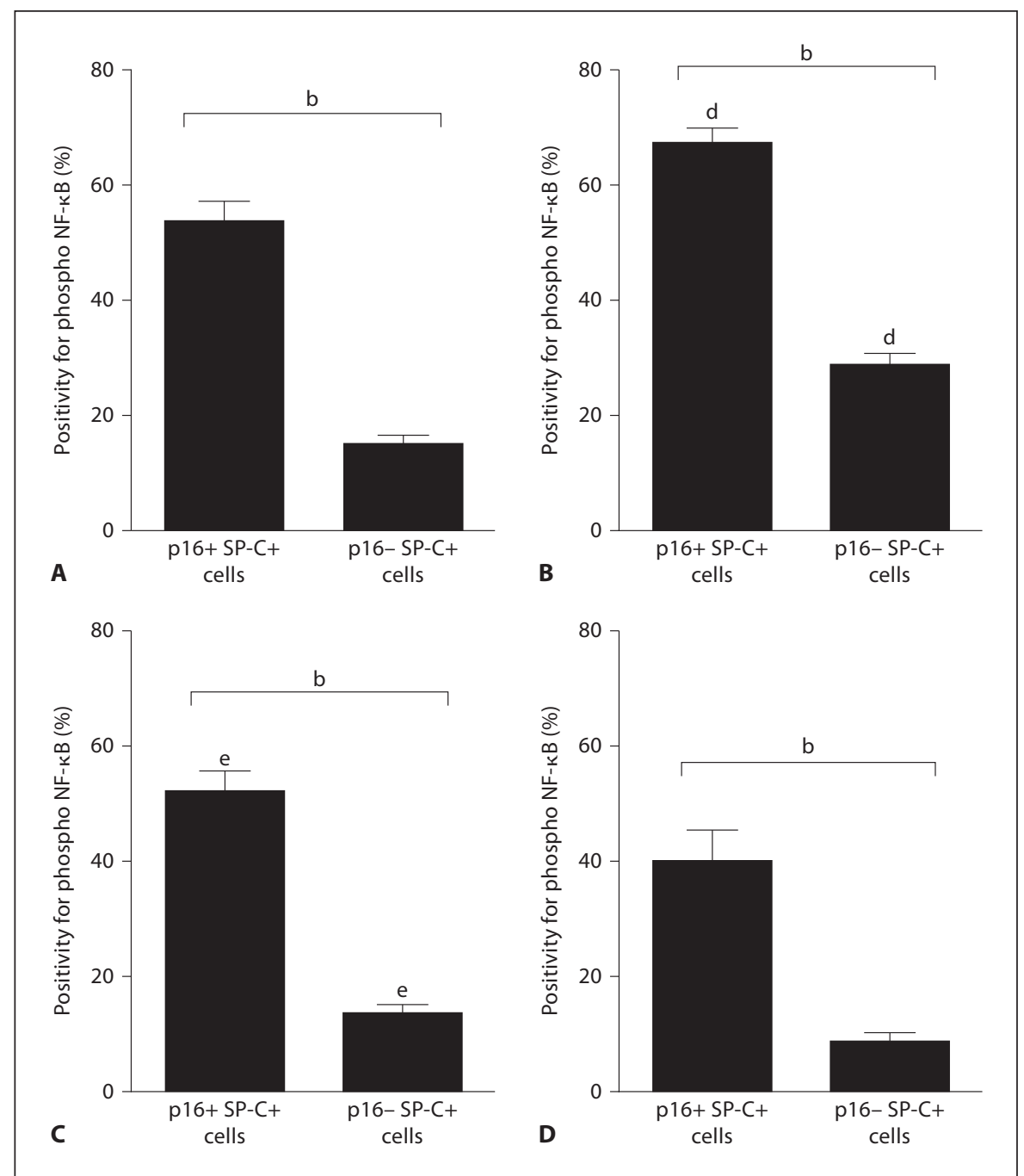

smokers and COPD patients included in this study were ex-smokers who had quit smoking at least 1 month before surgery, and the effects of smoking on type II cell senescence and NF- $\kappa$ B activation are unlikely to disappear after a brief period of smoking cessation.

The first limitation of the present study is that we used the A549 cancer cell line as an in vitro replica of alveolar epithelial cells, although it is not a good model for normal aging. However, we did not use cultures of normal type II epithelial cells because after long-term culture they undergo differentiation into type I-like cells rather than senescence. We did not use cultures of primary bronchial epithelial cells because serial passage of the cells induces squamous metaplasia rather than senescence. The second limitation is that we do not know whether other types of pulmonary cells, such as endothelial cells and fibroblasts, also exhibit a proinflammatory phenotype when they become senescent. In this context, recent studies have shown constitutive activation of inflammatory pathways in senescent human umbilical vein endothelial cells [25] and senescent skin fibroblasts [26]. In the present study, we also found that senescent HDMECs produced greater amounts of IL-6, IL- 8 and TNF- $\alpha$ than presenescent HDMECs. These results suggest that many types of cells, including cancer cells, normal cells, pulmonary cells and nonpulmonary cells, exhibit functional alterations to a proinflammatory phenotype. The third limitation is that we did not discriminate between replicative and stressinduced premature senescence in relation to its effect on NF- $\kappa \mathrm{B}$ activation. p16 ${ }^{\mathrm{INK} 4 \mathrm{a}}$ is known to be upregulated in cells subjected to replicative and premature senescence [22]. We speculate that the increased expression of 
p16 $6^{\text {INK4a }}$ in the type II cells of COPD patients represents both replicative senescence induced by increased cell turnover as a result of repeated apoptosis and proliferation $[14,39]$ and stress-induced premature senescence induced by DNA damage elicited by cigarette smoking [ 20 , 38]. However, whether NF- $\mathrm{B}$ activation is associated with replicative senescence, premature senescence or both is unknown. The fourth limitation is that the sample size of the human lung study is small, and future studies with large sample sizes are warranted.

Cellular senescence is characterized by loss of proliferative activity and is thought to be an evolutionary mechanism that protects against tumor development. However, the price is impaired tissue regeneration, which plays a role in the pathogenesis of COPD $[6,14]$. By showing that senescent alveolar epithelial cells undergo con- stitutive NF- $\kappa \mathrm{B}$ activation that is associated with upregulated production of proinflammatory mediators, the results of the present study provide evidence for a role of cellular senescence in chronic lung inflammation. We speculate that when alveolar epithelial cells reach the senescent stage, the lungs suffer not only from impaired alveolar regeneration but also exaggerated alveolar inflammation, both of which may contribute to the pathogenesis of COPD.

\section{Acknowledgments}

The authors are very grateful to Masayuki Shino and Yoshimi Sugimura for their technical assistance. This work was supported by a grant from the Ministry of Health, Labor and Welfare of Japan to investigate intractable diseases.

\section{References}

1 Franceschi C, Bonafè M, Valensin S, Olivieri F, De Luca M, Ottaviani E, De Benedictis G: Inflamm-aging. An evolutionary perspective on immunosenescence. Ann NY Acad Sci 2000;908:244-254.

$\checkmark 2$ Fagiolo U, Cossarizza A, Scala E, FanalesBelasio E, Ortolani C, Cozzi E, Monti D, Franceschi C, Paganelli R: Increased cytokine production in mononuclear cells of healthy elderly people. Eur J Immunol 1993; 23:2375-2378.

-3 Zanni F, Vescovini R, Biasini C, Fagnoni F, Zanlari L, Telera A, Di Pede P, Passeri G, Pedrazzoni M, Passeri M, Franceschi C, Sansoni P: Marked increase with age of type 1 cytokines within memory and effector/cytotoxic CD8+ T cells in humans: a contribution to understand the relationship between inflammation and immunosenescence. Exp Gerontol 2003;38:981-987.

-4 Meyer KC, Rosenthal NS, Soergel P, Peterson $\mathrm{K}$ : Neutrophils and low-grade inflammation in the seemingly normal aging human lung. Mech Ageing Dev 1998;104:169-181.

-5 Aoshiba K, Nagai A: Chronic lung inflammation in aging mice. FEBS Lett 2007;581: 3512-3516.

6 Karrasch S, Holz O, Jörres RA: Aging and induced senescence as factors in the pathogenesis of lung emphysema. Respir Med 2008;102:1215-1230.

7 De Martinis M, Franceschi C, Monti D, Ginaldi L: Inflamm-ageing and lifelong antigenic load as major determinants of ageing rate and longevity. FEBS Lett 2005;579: 2035-2039.

-8 Van Remmen H, Richardson A: Oxidative damage to mitochondria and aging. Exp Gerontol 2001;36:957-968. $\checkmark 9$ Chung HY, Kim HJ, Kim KW, Choi JS, Yu BP: Molecular inflammation hypothesis of aging based on the anti-aging mechanism of calorie restriction. Microsc Res Tech 2002; 59:264-272.

10 Hayflick L, Moorhead PS: The limited in vitro lifetime of human diploid cell strains. Exp Cell Res 1961;25:585-621.

11 Campisi J: Senescent cells, tumor suppression, and organismal aging: good citizens, bad neighbors. Cell 2005;120:513-522.

12 Herbig U, Ferreira M, Condel L, Carey D, Sedivy JM: Cellular senescence in aging primates. Science 2006;311:1257.

13 Jiang H, Schiffer E, Song Z, Wang J, Zürbig P, Thedieck K, Moes S, Bantel H, Saal N, Jantos J, Brecht M, Jenö P, Hall MN, Hager K, Manns MP, Hecker H, Ganser A, Döhner K, Bartke A, Meissner C, Mischak H, Ju Z, Rudolph KL: Proteins induced by telomere dysfunction and DNA damage represent biomarkers of human aging and disease. Proc Natl Acad Sci USA 2008;105:11299-11304.

-14 Tsuji T, Aoshiba K, Nagai A: Alveolar cell senescence in patients with pulmonary emphysema. Am J Respir Crit Care Med 2006 174:886-893.

15 Muller KC, Welker L, Paasch K, Feindt B, Erpenbeck VJ, Hohlfeld JM, Krug N, Nakashima M, Branscheid D, Magnussen $H$, Jorres RA, Holz O: Lung fibroblasts from patients with emphysema show markers of senescence in vitro. Respir Res 2006;7:32.

16 Chung KF, Adcock IM: Multifaceted mechanisms in COPD: inflammation, immunity, and tissue repair and destruction. Eur Respir J 2008;31:1334-1356.

17 Taraseviciene-Stewart L, Voelkel NF: Molecular pathogenesis of emphysema. J Clin Invest $2008 ; 118: 394-402$.
18 Douarre C, Gomez D, Morjani H, Zahm JM, O’Donohue MF, Eddabra L, Mailliet P, Riou JF, Trentesaux C: Overexpression of Bcl-2 is associated with apoptotic resistance to the G-quadruplex ligand 12459 but is not sufficient to confer resistance to long-term senescence. Nucleic Acids Res 2005;33:21922203.

19 Riou JF, Guittat L, Mailliet P, Laoui A, Renou E, Petitgenet $O$, Mégnin-Chanet F, Hélène $C$, Mergny JL: Cell senescence and telomere shortening induced by a new series of specific G-quadruplex DNA ligands. Proc Natl Acad Sci USA 2002;99:2672-2677.

20 Tsuji T, Aoshiba K, Nagai A: Cigarette smoke induces senescence in alveolar epithelial cells. Am J Respir Cell Mol Biol 2004;31:643649 .

21 Vasile E, Tomita Y, Brown LF, Kocher O, Dvorak HF: Differential expression of thymosin beta- 10 by early passage and senescent vascular endothelium is modulated by VPF/ VEGF: evidence for senescent endothelial cells in vivo at sites of atherosclerosis. FASEB J 2001;15:458-466.

22 Finkel T, Serrano M, Blasco MA: The common biology of cancer and ageing. Nature 2007;448:767-774.

23 Szulakowski P, Crowther AJ, Jiménez LA, Donaldson K, Mayer R, Leonard TB, MacNee W, Drost EM: The effect of smoking on the transcriptional regulation of lung inflammation in patients with chronic obstructive pulmonary disease. Am J Respir Crit Care Med 2006; 174:41-50.

24 Shelton DN, Chang E, Whittier PS, Choi D, Funk WD: Microarray analysis of replicative senescence. Curr Biol 1999;9:939-945. 
-25 Mariotti M, Castiglioni S, Bernardini D, Maier JA: Interleukin 1 alpha is a marker of endothelial cellular senescent. Immun Ageing 2006;3:4.

-26 Kriete A, Mayo KL, Yalamanchili N, Beggs W, Bender P, Kari C, Rodeck U: Cell autonomous expression of inflammatory genes in biologically aged fibroblasts associated with elevated NF-kappaB activity. Immun Ageing 2008;5:5.

-27 Rosseau S, Selhorst J, Wiechmann K, Leissner K, Maus U, Mayer K, Grimminger F, Seeger W, Lohmeyer J: Monocyte migration through the alveolar epithelial barrier: adhesion molecule mechanisms and impact of chemokines. J Immunol 2000;164:427-435.

-28 Fehrenbach H: Alveolar epithelial type II cell: defender of the alveolus revisited. Respir Res 2001;2:33-46.

-29 Barnes PJ, Karin M: Nuclear factor-kappaB: a pivotal transcription factor in chronic inflammatory diseases. N Engl J Med 1997; 336:1066-1071.
30 Yagi O, Aoshiba K, Nagai A: Activation of nuclear factor-kappaB in airway epithelial cells in patients with chronic obstructive pulmonary disease. Respiration 2006;73: 610-616.

31 Di Stefano A, Caramori G, Oates T, Capelli A, Lusuardi M, Gnemmi I, Ioli F, Chung KF, Donner CF, Barnes PJ, Adcock IM: Increased expression of nuclear factor-kappaB in bronchial biopsies from smokers and patients with COPD. Eur Respir J 2002;20:556-563.

32 Korhonen P, Helenius M, Salminen A: Agerelated changes in the regulation of transcription factor NF-kappa B in rat brain. Neurosci Lett 1997;225:61-64.

33 Helenius M, Hänninen M, Lehtinen SK, Salminen A: Aging-induced up-regulation of nuclear binding activities of oxidative stress responsive $\mathrm{NF}-\kappa \mathrm{B}$ transcription factor in mouse cardiac muscle. J Mol Cell Cardiol 1996;28:487-498.

34 Csiszar A, Wang M, Lakatta EG, Ungvari Z Inflammation and endothelial dysfunction during aging: role of NF-kappaB. J Appl Physiol 2008;105:1333-1341.
35 Salminen A, Huuskonen J, Ojala J, Kauppinen A, Kaarniranta K, Suuronen T: Activation of innate immunity system during aging: NF- $\mathrm{B}$ signaling is the molecular culprit of inflamm-aging. Ageing Res Rev 2008;7:83105.

36 Ito Y, Betsuyaku T, Nasuhara Y, Nishimura M: Lipopolysaccharide-induced neutrophilic inflammation in the lungs differs with age. Exp Lung Res 2007;33:375-384.

37 Beisswenger C, Platz J, Seifart C, Vogelmeier C, Bals R: Exposure of differentiated airway epithelial cells to volatile smoke in vitro. Respiration 2004;71:402-409.

>38 Nyunoya T, Monick MM, Klingelhutz A, Yarovinsky TO, Cagley JR, Hunninghake GW: Cigarette smoke induces cellular senescence. Am J Respir Cell Mol Biol 2006;35: 681-688.

39 Yokohori N, Aoshiba K, Nagai A: Increased levels of cell death and proliferation in alveolar wall cells in patients with pulmonary emphysema. Chest 2004;125:626-632. 